\title{
Sobre a Familiar 1.7 de Francesco Petrarca e a polêmica contra os velhos dialéticos
}

\author{
Sergio Xavier Gomes de Araújo \\ Bianca Fanelli Morganti*
}

\section{RESUMO}

A epístola 1.7 das Familiares de Petrarca, dedicada ao vitupério dos "mestres dialéticos", nos remete às batalhas travadas ao longo de toda a sua obra. Como é amplamente conhecido, a prosa latina é o campo preferido pelo poeta para expressar seus argumentos contra o saber nos moldes escolásticos conforme praticado nas grandes universidades da época, como a de Paris e a de Oxford. O texto encena o embate entre duas concepçóes antagônicas de filosofia; entre duas imagens inconciliáveis de sapientia em suas respectivas práticas discursivas: de um lado, como objeto de vitupério, surgem os "dialéticos" ou os magistri artium, providos de técnicas refinadas de argumentaçáo silogística instrumentalizadas em disputationes sem fim, de outro lado, desponta o ethos do sábio que Petrarca forja para si como preceptor de costumes à maneira de Sêneca, emulando uma noçáo de filosofia de caráter essencialmente moral e prático, como terapia ética contra as paixóes e como itinerário para a tranquilidade da alma e para a beatitude eterna.

Palavras-chave: Petrarca; Sêneca; Dialética; Artes liberais.

\section{ABSTRACT}

The epistle 1.7 of Familiares is dedicated to the vituperations at the "dialetic masters" and it is related to the battles taken over Petrarch's literary works. As it is widely known the latin prose is the field choosen by the Poet to express his ideas against the knowledge in the scholastic ways as practicated at the great universitaries centres of the period just like Paris and Oxford. In general lines the referred epistle acts out a collision between those two opposites conceptions of Philosophy, two irreconcilables images of sapientia in its respective discursives practices. On the one side, as vituperation's subject, the dialetics or the magistri artium are represented as men provided of very refinated techniques of silogistic's

DOI - http://dx.doi.org/10.1590/2237-101X016031002

Documento aprovado para publicação em 17 de setembro de 2015.

* Doutor em História Social da Cultura pela Pontifícia Universidade Católica do Rio de Janeiro (PUC-Rio) e professor na Universidade Federal de São Paulo (Unifesp). São Paulo, SP, Brasil. E-mail: sergioxg@ig.com.br.

** Doutora em Teoria e História Literária pela Universidade Estadual de Campinas (Unicamp) e professora na Universidade Federal de São Paulo (Unifesp). São Paulo, SP, Brasil. E-mail: bianca.morganti@unifesp.br. 
argumentation frequently instrumentalized in infinite disputationes. On the other side emerges the sage`s ethos that Petrarch forges for himself as a moral preceptor in Seneca's manner, emulating a notion of Philosophy characterized essentially by a moral and practical content, as an ethical therapy against the passions and as route to the tranquility of soul and to eternal beatitude.

Keywords: Petrarch; Seneca; Dialetics; Liberal arts.

$\mathrm{Na}$ carta ad socratem suum ${ }^{1}$ que serve de proêmio à coleção de suas correspondências privadas, os "Livros das coisas familiares" — ou simplesmente "Epístolas Familiares" —, Petrarca apresenta sua obra atentando para o quanto difere da coesão e harmonia que vê nos modelos antigos, como as cartas de Cícero e de Sêneca. Seu corpus epistolar destaca-se, como ele enfatiza, pela disformidade e mesmo pela incoerência, composto de escritos "diversificados e contraditórios" 2 dados pela variedade das circunstâncias e dos afetos; tão diferentes entre si nas matérias e no estilo que só mesmo um sentimento frívolo da própria glória poderia levá-lo a presumir que pudessem ser lidos sem fastio a náo ser por um amigo, já que este, ressalta Petrarca, é um alter ego. ${ }^{3}$ De todo modo, apesar da modéstia, seu esforço nesta carta proemial é o de justificar-se e de se afirmar face à autoridade dos antigos. Evoca mais adiante como razáo da singularidade de sua forma um elemento fundamental do gênero epistolar, da exigência de adequar as cartas aos caracteres e disposiçôes específicas dos destinatários: "O primeiro cuidado dos que escrevem é o de estar atento àquele para quem se escreve; este é, com efeito, o único modo de compreender não só a matéria, mas também o tom e as restantes circunstâncias da carta."

Para introduzir-nos às suas Familiares, assim, Petrarca marca desde já sua diferença em relação aos modelos e explicita seus desígnios próprios. Procura alegar a plena legitimidade de sua mobilização particular dos preceitos que regulavam a epistolografia - ou sermo familiaris - da Antiguidade. A carta familiar era entendida pelos antigos como gênero que deve imitar o modo simples e coloquial da conversa entre amigos, tendo o aconselhamento como mais alta prerrogativa. Agiria assim no sentido de produzir o efeito da presença dos interlocutores ausentes, daí o célebre topos de que quem escreve a carta escreve um retrato

\footnotetext{
${ }^{1}$ Seguindo seu hábito de traduzir os nomes de seus mais caros amigos em estilo clássico, Petrarca chama Sócrates ao destinatário desta carta introdutória. Trata-se de Louis Santus de Berigen, que o poeta conhecera na corte papal de Avignon como cantor na capela do cardeal Giovanni Collona. Petrarca endereça ao mesmo interlocutor mais 22 cartas nas Familiares. DOTTI, Ugo. Introduction. In: Pètrarque, Lettres Famillières, IIII. Paris: Les Belles Lettres, 2002, p. 342.

${ }^{2}$ PETRARCA, Familiares, 1.1.19.

${ }^{3}$ Ibidem, 1.1.30

${ }^{4}$ Ibidem, 1.1.28. Sobre o preceito da adequação da carta aos caracteres do destinatário ver Cícero, Epistulae ad familiares, 2.4.1; 4.13.1.
} 
do próprio ânimo. ${ }^{5}$ Tal ideia assume particular relevância na maneira como Petrarca pensa o projeto do epistolário. A certa altura, refere-se a seus escritos justamente como "retrato de meu ânimo" e "imagem do meu engenho" e sugere a comparação entre seu trabalho de escritor e a arte do escultor grego Fídias, famoso por ter modelado a estátua de Minerva. Como nos faz saber, ele se aplica de modo análogo na elaboraçấo de sua obra, de modo calculado e cuidadoso, segundo um plano determinado de construção da própria imagem. ${ }^{6}$ A ordem e o estilo dos escritos, explica o poeta, deveriam dar a ver o vigor de seu espírito - especialmente na juventude - consolando a si mesmo e aos outros; e deveriam ainda dar a ver a sua aversão profunda à fraqueza como traço mais marcante de seu caráter, uma vez que enfrentou sempre com coragem os mais duros golpes da fortuna, do exílio, da doença, da perda do patrimônio e da diminuição de sua glória. ${ }^{7} \mathrm{O}$ caráter "diversificado e contraditório" de seu corpus de escritos corresponde assim ao retrato que Petrarca deseja forjar de si no livro; confere expressão às "tempestades da vida" ao longo das quais, como enfatiza, tivera que responder a múltiplas solicitaçôes tanto por parte de amigos como de "inumeráveis conhecidos" de caracteres e condiçôes variados, por isso precisara mostrar-se "diferente de si mesmo" de uma carta a outra, movido pelo imperativo moral do aconselhamento. ${ }^{8}$

O ethos epistolar das Familiares desponta deste modo como modelo de virtude e sabedoria pela versatilidade com que se recompóe a cada vez de modo a abranger os mais diversos tipos de situaçôes, dadas pelas circunstâncias específicas do temperamento e hábitos dos interlocutores e por seus problemas imediatos. Teria sido bem mais fácil aos antigos alcançar uma forma mais bela e bem-acabada com unidade de disposição, pois que em geral haviam tido que habituar-se aos caracteres de um só ou de alguns poucos: Epicuro, sublinha Petrarca, falava somente a dois ou três indivíduos, Cícero a quase o mesmo número e Sêneca pra-

\footnotetext{
${ }^{5}$ Os preceitos do sermo familiaris aparecem de modo disperso nas cartas de Cícero e de Sêneca. Há, porém, um breve excurso no tratado De Elocutione de Demétrio que trata dos preceitos do sermo mais propriamente como arte. Demétrio confere ao gênero a função da manutenção da amizade, devendo tratar de matérias simples em estilo simples. No plano da elocuçấo suas qualidades principais devem ser as da brevidade e da clareza, incompatíveis com o tom declamatório e demasiadamente ornado da eloquência dos fóruns e assembleias - "hoc mediocre domesticum et familiare dicendi genus." DEMÉTRIO, 1.1 16. Da carta familiar como imitação da conversação oral, ver CÍCERO, Ad atticum, 12.53; SÊNECA, Epistulae ad Lucilium, 38. Da função do aconselhamento — docere - ver SÊNECA, Epist. ad Lucil., 75.1. Da carta como modo de tornar presentes os amigos ausentes e como retrato do ânimo ver CÍCERO, Epistulae ad familiares, 16.16.2; SÊNECA, Epist. ad Lucil., 40. Sobre o assunto ver TIN, Emerson. A Arte de escrever cartas. São Paulo: Editora da Unicamp, 2005.

${ }^{6}$ Designa suas cartas na passagem em questão como "animi mei effigiem" e "ingenii simulacrum" valendo-se da comparação que Cícero faz no De Oratore (2.17. 73) entre o orador alcançando o ápice da eloquência e a arte de Fídias dando os últimos retoques à estátua de Minerva. Cf. PETRARCA, Fam., 1.1.37. A composição das Familiares teria ocorrido, sobretudo, em três etapas aproximadamente entre 1351 e 1366. De julho de 1351 a abril de 1353 em Vaucluse; entre 1359-1360 em Miláo; 1364-1366 em Miláo. ROSSI, Vittorio, Sulla formazione delle raccolte epistolari petrarcesche. Apud. DOTTI, Ugo. Vida de Petrarca. São Paulo: Editora da Unicamp, 2006, p. 256.

${ }^{7}$ PETRARCA, Fam. 1.1. 38-41.

${ }^{8}$ Ibidem, 1.1. 27-30.
} 
ticamente só a Lucílio. ${ }^{9}$ Deste modo enfim insta seu interlocutor de preferência a comparar sua vida com a história das viagens de Ulisses. Tal como fora necessário ao grande herói da Odisseia pôr em prática muitas línguas e estratégias em suas viagens — nos inúmeros lugares que visitara e diante de cada antagonista - , o autor das Familiares tivera que saber transformar seu estilo e adaptar seus temas às ocasióes concretas que se lhe apresentaram em seu difícil itinerário sobre a terra. ${ }^{10}$

Conforma-se em suma no texto das "familiares" uma figura de letrado como homem de ação, hábil em extrair do vastíssimo repertório clássico as formas, argumentos, exempla e sententiae mais úteis e apropriados às condições variadas de interlocução. Trata-se mesmo do bom discernimento ou do senso de conveniência tão celebrado por Cícero e por Quintiliano como entre as mais distintivas qualidades do vir bonus dicendi peritus, ${ }^{11}$ decorrente não tanto de sua instrução teórica nas artes do discurso, mas antes de sua sabedoria prática — prudentia. ${ }^{12}$ É este senso de conveniência que determina as maneiras como Petrarca emprega as mais diversas autoridades, de Cícero a Sêneca, de Macróbio a Ovídio e a Santo Agostinho, efetuadas como atos de apropriação - e não como reprodução da forma ou adesão pessoal às ideias - que as atualizam e as tornam ativas. ${ }^{13}$

Ao pautar-se não numa reverência cega, mas no sentido de seus usos apropriados ou virtuosos, tal maneira de relacionar-se com a herança clássica se consolidaria mais tarde como paradigmática das práticas literárias dos humanistas. Como já foi dito, este espaço textual, no colóquio vivo em que Petrarca repóe e faz circular suas leituras, faz-se lugar de uma nova solidariedade entre espíritos; efetiva-se como res publica de letrados composta de homens que partilham o mesmo gosto pelos autores clássicos e a crença de que seu cultivo leva à formação de homens "nobres e livres". ${ }^{14}$ Os vários personagens com que Petrarca

\footnotetext{
${ }^{9}$ Ibidem, 1.1.20.

${ }^{10}$ Ibidem, 1.1. 20-30. "Petrarca não se contenta em utilizar o mito na chave biográfica, mas o transfere ainda, por assim dizer, para o plano metaliterário." CARRAI, Stefano. Il Mito di Ulisse Nelle Familiari. In: BERRA, Claudia (Org.). Motivi e Forme delle Familiari di Francesco Petrarca. Miláo: Monduzzi Editore, 2003, p. 171.

${ }^{11}$ Cf. QUINTILIANO. Institutio Oratoria, 12.1.1: "Que seja então o nosso orador, aquele que constituímos, tal como é definido por M. Catão: um 'homem bom, perito em falar.' Na realidade, o que o próprio Catâo colocou em primeiro lugar, e que pela própria natureza é maior e mais importante: acima de tudo, ser um homem bom..."

12 "Que ele saiba regrar esta elocução segundo consideraçôes de circunstâncias e de pessoas, ele merecerá ser louvado por este gênero de mérito que chamo de justeza e conveniência." CÍCERO. De Oratore, 3. 53. QUINTILIANO, Institutio Oratoria, 3.50.

13 "Petrarca pode ressuscitar os antigos porque sabe que combinação de suas palavras invocar em cada situação dada." QUILLEN, Carol. Rereading Renaissance Humanism, Petrarch, Augustine, and the language of Humanism. Michigan: University of Michigan Press, 1998, p. 119.

${ }^{14}$ Sobre isso ver GARIN, Eugenio. A prosa latina do século XV. In: Idade Média e Renascimento. Lisboa: Editora Estampa, 1994, p. 103; QUILLEN, Carol. Petrarch's Correspondence and Humanist Practice. In: QUILLEN, Carol. Rereading Renaissance Humanism, Petrarch, Augustine and the language of Humanism, op. cit., p. 114. STRUEVER, Nancy. Petrarchan Ethics: Inventing a Practice. In: STRUEVER, Nancy. Theory as Practice. Ethical Inquiry in the Renaissance. Chicago: University of Chicago Press, 1992, p. 6; CELENZA,
} 
interage, regrando a forma de suas cartas, possuem este decisivo traço em comum: são em geral poetas, oradores, patronos e chanceleres que, como ele próprio, dedicam-se às bonnae litterae. Este círculo de letrados reforça amiúde sua conciliação interna qualificando ética e intelectualmente seus antagonistas. É o caso do anônimo mestre de dialética que Petrarca toma como seu objeto na breve epístola 1.7, conhecida como epístola "Contra os velhos dialéticos", cuja tradução em língua portuguesa se apresenta aqui: ao que tudo indica, trata-se do representante de uma das mais proeminentes expressóes discursivas do saber nos moldes escolásticos, cuja distância da dignidade e excelência do latim dos antigos o situa entre as principais personagens que esta res publica das letras deve expulsar de suas fronteiras.

"Contra os velhos dialéticos" integra um grupo de cartas do primeiro volume da coletânea endereçadas ao poeta siciliano Tommaso Caloiro, que Petrarca conhecera à época de seus estudos jurídicos em Bolonha. A figura de Tommaso, por ser mais jovem e suscetível aos excessos das paixóes, faz com que Petrarca adote nestes escritos um ethos de preceptor de costumes e das artes do discurso à maneira de Sêneca, contrariando, portanto, aquele que diz ser o programa de seu estilo mais próximo à familiaridade de Cícero do que do tom filosófico de Sêneca. Se já o destinatário e o ethos do próprio orador nos dá pistas da importância do modelo senequiano nesta composição, o tema da epístola — a crítica petrarquista aos dialéticos do seu tempo e à sua linguagem como índice da deformidade de seus caracteres - confirma Sêneca como guia primeiro. O texto distingue-se, desse modo, no corpus das Familiares por empregar elementos característicos da invectiva, ${ }^{15}$ cuja finalidade, como se sabe, é o vitupério de alguém ou de alguma ação; suas provas mais utilizadas são as relativas ao ethos, à descrição dos caracteres: se o encomium visa construir a imagem de alguém como honestum, a invectiva forja, por outro lado, o retrato do turpe. Petrarca exercita-se, portanto, no tom áspero e agressivo que é próprio ao vitupério nesta carta, mobilizando seus materiais para fazer do dialético essa persona turpe. Por um lado, se já o exórdio da carta é capaz de remeter, imediatamente, o seu leitor ao campo de batalhas travadas, de modo mais ou menos direto em toda a obra latina de Petrarca, contra os, oportunamente, chamados "dialéticos", a

Christopher. The Humanists of The Classic Era on Social Place. In: The Lost Italian Renaissance. Baltimore: John Hopkins, 2005, p. 121-124.

${ }^{15}$ Esta carta conta-se entre as muitas partes polêmicas que aparecem nas correspondências de Petrarca, das Familiares à coleção das cartas da velhice - Seniles. Surgem elementos do gênero ainda nos tratados morais, tais como o De Vita solitária e o De remediis utriusque fortunae. Mas as mais célebres e importantes obras deste tipo são sem dúvida as duas grandes invectivas: De sui ipsius et multorum ignorantia e o Contra medicum. Como aponta o estudioso Francesco Bausi, Petrarca parece tomar a maneira dialética da invectiva como sua forma mentis, apropriando-se com frequência da situação de confronto com um adversário ou alguma coisa, representantes em geral das tendências hegemônicas na cultura e na vida intelectual de sua época, como modo mais adequado para a expressão de suas próprias perspectivas fundadas na excelência do passado clássico e latino. Sobre o assunto ver MORGANTI, Bianca Fanelli. Invective contra Medicum de Francesco Petrarca: tradução, ensaio introdutório e notas. Tese (doutorado em Teoria e História Literária) — Programa de Pós-Graduação em Teoria e História Literária, Universidade Estadual de Campinas. Campinas, 2008; BAUSI, Francesco. Petrarca Antimoderno. Florença: Franco Cesati Editore, 2008, p. 194. 
passagem seguinte (1.7.2) nos apresenta a tese que norteará toda a epístola, ao mesmo tempo que insinua ao leitor a autoridade principal à qual o poeta pretende articular outras autoridades e outros exemplos para reforçar o seu edifício argumentativo. ${ }^{16}$ Assim, para conectar a crítica ao terminalismo que caracterizaria os "dialéticos" de seu tempo ao princípio segundo o qual haveria uma perfeita correspondência entre modos de expressão linguística e o caráter de quem fala, Petrarca percorrerá, como via principal, diversas das Epistulae Morales ad Lucilium, que lhe fornecerão os argumentos e os lugares convenientes que, atualizados, fundamentarão a sua posição. ${ }^{17}$

Na epístola 114 de Sêneca a Lucílio, encontra-se um provérbio já de longa tradição, que o preceptor romano teria tomado dos gregos: talis hominibus oratio fuit qualis vita (a elocução de tais homens foi como as suas vidas). ${ }^{18}$ Se no contexto senequiano o preceptor lança mão do provérbio para mostrar ao discípulo como os vícios de linguagem podem denotar a decadência moral de toda a sociedade de uma época, no discurso de Petrarca ao jovem Tommaso os ecos dessa tópica adquirem contornos mais particulares e lhe permitirão defender que os vícios de linguagem de seus adversários espelham o equívoco do caminho que eles propóem para a educação do homem cristão, e consequentemente a errônea concepção de sabedoria e, em última instância, de filosofia sustentadas por este grupo crescente de intelectuais. Não demora, portanto, para que Petrarca passe do vitupério à escrita do adversário, vista como uma confissão de sua ignorância, para o ataque de todo um modelo filosófico cujo fim não corresponderia à concepção petrarquista de sumo bem, e, por isso, não serviria à educação do homem cristão. O contato com a crítica de Petrarca àqueles que "tiram seu máximo prazer da contenda e têm por propósito não encontrar o verdadeiro mas altercar" ${ }^{19}$ nos remete, de imediato, aos memoráveis passos de Sêneca sobre a dialética que, sabemos, não escaparam a Petrarca, assim como não lhe escaparam o provérbio atribuído a Varrão e a passagem das Instituiçóes Oratórias de Quintiliano, todas autoridades articuladas logo no início da epístola. ${ }^{20}$

A posição de Sêneca em relação à lógica não é simples e unívoca; não se trata de uma recusa peremptória, mas de um reposicionamento do argumento dialético no interior do processo terapêutico proposto pela sua filosofia. Sêneca não se dirige a um grupo específico

\footnotetext{
${ }^{16}$ Sobre este procedimento combinatório de autoridades, o próprio Petrarca nos fornece alguns esclarecimentos no prólogo do seu De viris illustribus. Cf. PETRARCA. De viris illustribus, a cura di G. Martellotti. Florença, Milão, Nápoles: Riccardo Ricciardi Editore, 1954, p. 220. Francesco Bausi, analisando uma passagem específica das Invective contra medicum (2.122-152) a propósito do método historiográfico de Petrarca, observa certo procedimento que define como um costume petrarquista de utilizar simultaneamente diversas autoridades, e de reforçar uma autoridade "principal", sobre a qual se organiza o discurso, com outra autoridade "secundária". Cf. BAUSI, Francesco. Il mechanicus che scrive libri. Per un nuovo commento alle Invective contra Medicum di Francesco Petrarca. Florença: Leo S. Olschki Editore, 2002, p. 94-97.

${ }^{17}$ Vale ressaltar que a identidade entre vida e modo de falar é, tradicionalmente, remontada à Socrates, segundo os testemunhos de Platão (Rep. 3.400d) e Cícero (Tusc. 5.47).

${ }^{18}$ Cf. SÊNECA, Epist. ad Lucil., 114.

${ }^{19}$ Cf. PETRARCA, Fam., 1.7.3.

${ }^{20}$ Ibidem, 1.7.4.
} 
ou a uma escola filosófica, mas recusa o uso da argumentação lógica nos dois estágios iniciais do tratamento das almas. De acordo com essa terapia, aqueles que desejam tomar uma nova direção espiritual, libertando sua alma da "doença” que a aflige ${ }^{21}$ — as paixôes — precisarão primeiramente conter esse impulso violento que é insensível à razão. Às frequentes metáforas médicas, Sêneca associa todo um vocabulário militar para então definir essa primeira ação curativa como uma verdadeira batalha contra as paixôes. ${ }^{22}$ Apenas no último estágio da terapia o filósofo pode abrir mão do apelo retórico às emoçóes que caracterizam as duas etapas anteriores. No modelo discursivo adequado aos já instruídos nos fundamentos da sabedoria, a argumentação lógica ou dialética desempenharia, então, papel preponderante. É, portanto, no contexto da terapia ética proposta por Sêneca nas Epístolas a Lucílio que estão situadas as suas críticas aos dialéticos. Petrarca, contudo, desloca os argumentos senequianos para outro contexto, e ressignifica toda a tópica. ${ }^{23}$

Também a posição de Petrarca no confronto com o que entende por dialética é mais complexa do que pode parecer à primeira vista. ${ }^{24}$ Igualmente distante de uma recusa peremptória da dialética e, especificamente da lógica de matriz aristotélica e da própria autoridade de Aristóteles, Petrarca encontra nas metáforas náuticas de Sêneca as imagens mais adequadas à crítica que expressará em diversas das suas obras latinas. Repondo mais uma vez o famoso motivo das errâncias de Ulisses, mas dessa vez a partir da interpretação senequiana, ${ }^{25}$ Petrarca também comparará a vida do homem a uma atribulada viagem marítima cujo porto final é a beatitude da vida imortal. Seus adversários, ignorantes da verdadeira meta e seduzidos pelos meios, vagam sem jamais alcançarem os fins. Petrarca repóe na Familiar 1.7 a grande questão moral, também explorada por Sêneca nesta mesma epístola 88, de qual deve ser a finalidade dos estudos liberais na educação do homem. Mas ao abordar o tema, transfere a crítica senequiana aos limites das artes liberais para um novo contexto, e toma por alvo a nova linguagem lógica que vinha sendo defendida pelos "dialéticos" do seu tempo. Com frequência, Petrarca insiste não atacar toda a Lógica, atribuindo-lhe a importância que merece como uma das

\footnotetext{
${ }^{21}$ Para o vocabulário e as metáforas médicas, bem como para a analogia entre medicina e filosofia recorrentes na filosofia consolatória antiga e amplamente difundidas em Sêneca, cf. ARMISEN-MARCHETTI, Mireille. Sapientiae facies: Étude sur les images de Sénèque. Paris: Les Belles Lettres, 1989, p. 132-138 e p. 347ss.; e ainda, NUSSBAUM, Martha. The Therapy of Desire: Theory and Practice in Hellenistic Ethics. Princeton: Princeton University Press, 1994, p. 6ss.; FICCA, Flaviana. Remedia doloris. La parola come terapia nelle “Consolazioni” di Seneca. Nápoles: Loffredo, 2001, p. 165-169.

${ }^{22}$ Sobre o vocabulário médico e militar característico do gênero consolatório e a relação desse gênero com a terapia contra as paixóes de Sêneca e o estilo das Epistolas Morais a Lucílio, cf. SETAIOLI, Aldo. Facundus Seneca. Aspetti della lingua e dell'ideologia senecana. Bolonha: Pàtron, 2000, p. 241.

${ }^{23}$ Para as críticas aos dialéticos em algumas das epístolas de Sêneca, cf. Epist. ad Lucil. 45. 3-5. E ainda, epístolas $48,49,82,102,108,109,111,117$.

${ }^{24}$ Nos tempos de Petrarca, o termo "dialética" designava, primeiramente, a terceira das artes do trivium (gramática, retórica e lógica), e se concentrava no estudo formal da lógica aristotélica. Para a definição da disciplina, cf. Isidoro de Sevilha, Etymologiae 2.22.1.

${ }^{25}$ Cf. SÊNECA, Epist. ad Lucil. 88.7.
} 
artes liberais. Mas entende que, como as demais artes liberais, a dialética é propedêutica; fornece aos homens conhecimentos úteis para a aquisiçâo de saberes mais elevados.

Partilhando da doutrina de Agostinho, Petrarca entende que a dialética não pode ser tomada como fim em si, e seus adversários vagam náufragos ao se dedicarem a ela como se fosse algo digno de fruição, pois demonstram ignorar a cristalizada diferença entre as coisas que devem ser fruidas e as coisas que devem ser utilizadas. Seguindo os pressupostos doutrinais que assumira, Petrarca acusa parte de seus contemporâneos dados aos estudos lógicos de se perderem em meio a discussóes vás que, fundadas apenas nas palavras e desprovidas de qualquer preocupação com a graça divina, seriam caracterizadas pela falta de aplicação prática e por ter como objetivo último a contradição do adversário. Na perspectiva petrarquista, as inúteis discussóes dialéticas não contribuíam para a felicidade do homem. Tendo mais clara do que seus adversários a distinção agostiniana entre as coisas que devem ser fruídas e as coisas que devem ser utilizadas com vistas à fruição de Deus, fim último de toda criatura, ${ }^{26}$ Petrarca considerava que a fruiçáo daquilo que é apenas instrumento afasta o homem de sua pátria, para usar uma metáfora de Agostinho. ${ }^{27}$ Em outras palavras, para Petrarca, a verdadeira sabedoria é o exercício da virtude, é aquela que leva o homem ao reconhecimento dos limites impostos à sua natureza mortal, e o torna consciente da sua existência transcendental e eterna. Consequentemente, o homem verdadeiramente sábio reconhece a necessidade da fé, e a exigência da efetuação dos preceitos estabelecidos pela moral cristâ, único modo de ascender à contemplação divina. Trata-se, portanto, de um saber agir de modo a amar a Deus, e buscar a comunhão na qual o homem realiza plenamente sua existência; e para a aquisição desta sabedoria prática, pouco auxiliariam as investigaçóes naturais, as estéreis disputas dialéticas ou qualquer imperfeita ciência humana. Visando reforçar a ideia de que a dialética é um conhecimento propedêutico, que deve ser adquirido em idade pueril, como instrumento para outras etapas subsequentes do processo de progressão moral que conduz o homem à felicidade, Petrarca introduz um elemento frequente na sua crítica aos dialéticos: a ridicularizaçáo do ethos dos adversários, que, já velhos, seguem se dedicando a atividades de meninos. A pecha de velhos ignorantes dos verdadeiros fins, ignorantes do verdadeiro caminho da salvação e aprisionados em brincadeiras pueris contribui para invalidar a imagem de sábio defendida por este novo modelo de racionalidade em voga. ${ }^{28}$

Como se sabe, na segunda metade do século XIV, muitas das inquietudes que mobilizaram os debates no ambiente escolástico do século anterior a Petrarca já haviam sido mais ou menos aplacadas. Se, por um lado, as condenaçôes do Silabo de Tempier ainda ecoavam sobretudo nos círculos religiosos, por outro, sabe-se que o recurso à dupla verdade — expresso por locuçôes como loquor ut naturalis - empregado para relativizar as discordâncias entre

\footnotetext{
${ }^{26}$ Cf. AGOSTINHO, De doctrina christiana, 1.3 e 1.5.

${ }^{27}$ Ibidem, 1.5 .

${ }^{28}$ Cf. PETRARCA, Invectiva contra medicum e De ignorantia. Para o decoro das atividades em cada etapa da vida, cf. CÍCERO, De officiis.
} 
a verdade revelada e as deduçóes da filosofia natural era já amplamente difundido nas obras dos mestres das Faculdades de Artes. ${ }^{29}$ E a separação entre teologia e filosofia, determinada em grande medida pelos impactos causados sobretudo pela produção de Duns Scott, ${ }^{30}$ bem como a consequente necessidade da busca de uma logica fidei se impunham cada vez mais decisivamente também entre os teólogos. ${ }^{31}$

Petrarca fala precisamente contra esse novo modelo de racionalidade. Seguindo a trilha de um Boaventura (1221-1274), busca no debate do século anterior ao seu os argumentos-chave para a defesa de um modelo antagônico, centrado não nessa sapientia philosophica mas numa sapientia christiana de ascendência agostiniana. Nesta perspectiva, não há qualquer outra finalidade para o conhecimento que não a salvaçáo da alma, e a unidade do saber, além de ferramenta de subordinaçấo hierárquica de cada uma das "ciências" à teologia, se converte em critério mesmo da verdade que lhes é intrínseca. ${ }^{32}$ A doutrina de Boaventura, como a agostiniana, estabelece como meta o amor a Deus, e entende, portanto, que todas as vias capazes de conduzir o homem a Ele pertencem à teologia; as ciências do homem, entre as quais a "filosofia pagã", podem apenas auxiliá-lo. Neste sentido, a doutrina do mestre franciscano também consiste num itinerário da alma até Deus; ela busca ensinar por qual modo o homem tende, por coisas diversas, em direção a Deus, e precisamente nisto consistiria toda a filosofia: em mostrar este universo cujos objetos ensinam sobre Deus e inclinam a ele. Assim, em contraposição a esse novo modelo - fundado sobre uma imagem do saber como construção humana, desprovida de pretensão apologética e representada por uma rede de teoremas sintaticamente válidos mas nem sempre verdadeiros, quando submetidos ao critério absoluto da fé - Petrarca contrapóe o antigo modelo de Agostinho, e depois de Boaventura, emulado na imagem do sábio ciceroniano, mas moralizado até fundar-se numa sapientia cristocêntrica capaz de eliminar qualquer contradição entre crer e compreender.

$\mathrm{O}$ embate entre as posições dos chamados modernos e aquelas defendidas por Petrarca coloca em conflito duas concepçóes de sapientia, duas imagens inconciliáveis do sábio, dois modelos de linguagem diversos e dois percursos pedagógicos distintos. Ao genérico conceito de filosofia como "amor da sabedoria", largamente utilizado por Petrarca nas suas Invectivas, ${ }^{33}$ que permitia que todo cristão, enquanto possuidor da verdade revelada, fosse

\footnotetext{
${ }^{29}$ Sobre a dupla verdade e a condenaçáo de 1277, cf. BIANCHI, Luca. Il Vescovo e I filosofi — La condanna parigina del 1277 e l'evoluzione dell'aristotelismo scolastico. Bérgamo: Pierluigi Lubrina Editore, 1990; para os rumos tomados pelas diversas interpretaçóes de Aristóteles nos diferentes ambientes intelectuais do século XIV e suas consequências para a distinção entre filosofia e teologia, cf. BIANCHI, Luca; RANDI, Eugenio. Le verità dissonanti - Aristotele alla fine del medioevo. Roma-Bari: Laterza, 1990.

${ }^{30}$ Sobre a importância de Duns Scott, cf. ibidem, p. 68.

${ }^{31}$ Para a substituição da lógica aristotélica (logica naturalis) por uma logica fidei, mais adequada às exposiçóes teológicas, cf. ibidem., p. 72.

${ }^{32}$ Ibidem, p. 39-40.

${ }^{33}$ Cf. PETRARCA, Inv. contra medicum, 2. 288: "Filósofo, como o próprio nome demonstra, é o 'amante da sabedoria: tu és escravo do dinheiro."
} 
chamado filósofo, contrapóe-se uma concepção mais restrita, mais técnica. O filósofo passa a ser definido a partir de uma noção específica de sábio, pautada na descrição fornecida por Aristóteles no livro VI da Ética a Nicômaco e identificada, no século XIV, com os magistri artium. Esta nova imagem do filósofo correspondia à de um cultor profissional da verdade, provido de uma linguagem especializada, e não mística, isto é, provido de técnicas demonstrativas, argumentativas e de um arsenal de conceitos que Petrarca dizia ser instrumentalizados em disputationes sem fim que seus adversários acreditavam ser a verdadeira sabedoria. Para Petrarca, a verdadeira sabedoria é toda outra, se funda na consciência da condição mortal do homem, na percepção de que essa vida é um itinerário para a verdadeira vida, e na compreensão de que, se a filosofia é o amor da sabedoria, e para um homem cristão Deus é a máxima sapiência, logo, para um verdadeiro cristão não há possibilidade de filosofia fora do amor de Deus e, portanto, não há possibilidade de separaçáo entre teologia e filosofia. É, então, contra esse modelo "monstruoso" criado por bárbaros de Oxford e Paris, e já disseminado por todo o solo italiano até a Sićlia sob a forma de quaestiones, que Petrarca contrapõe uma outra linguagem, um modo de expressão regulado pelos preceitos da retórica, ensinado pelas autoridades e pelos exemplos, e aperfeiçoado pelo estudo das obras dos antigos; modo de expressão esse conveniente ao caráter e à vida do sapiens christianus.

Petrarca, portanto, centra sua atenção na condição existencial do homem e estende os critérios do juízo moral a toda atividade intelectual, atribuindo primazia à mensagem ética sobre qualquer lição cognoscitiva. O juízo moral tem, para o poeta, valor universal e edificante, enquanto todo o saber humano, incluindo a dialética, é apenas parte de uma sabedoria maior e indefinida. É nesse sentido que ele recusa a postura dos seus adversários, considerando-a soberba filosófica. Petrarca, reforçando as limitações impostas ao homem por sua natureza mortal, defende uma noção de conhecimento intelectual que coincide, necessariamente, com a consciência ética do sábio. Como se trata, obviamente, de uma ética cristâ, o poeta retoma a máxima platônica, reposta por Cícero e por Sêneca, e define que a vida do filósofo nada mais é do que preparação para a morte. ${ }^{34}$ Assim, a única felicidade possível, para Petrarca, é fruto não das operaçôes puramente intelectuais que seus adversários consideram levar ao sumo bem, mas sim da certeza da correta orientaçáo em direçáo à felicidade, certeza esta fundada na máxima apolínia nosce te ipsum. Apenas o conhecimento de si mesmo leva o homem a tomar consciência da sua imperfeição e do amor que sente pela perfeição. Recusando a concepção de filosofia e de filósofo em voga nos ciclos escolásticos, Petrarca admite apenas uma filosofia entendida como meditatio mortis, e um filósofo à imagem dos grandes médicos de alma de todos os tempos.

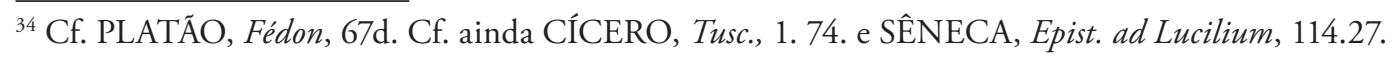




\section{Francesco Petrarca, Familiares, $1.7^{35}$}

\section{A Tomás de Messina, contra os velhos dialéticos}

[1] É temerário bater-se com inimigo que busca não tanto a vitória quanto o combate. Tu me escreves que um certo velho dialético, fortemente abalado por uma carta minha como se nela eu condenasse seu artifício, por isso reclama publicamente e ameaça ele próprio investir contra nossos estudos numa carta sua. Tu me escreves ainda que, por muitos meses, tens esperado essa carta em vão. [2] Não a esperes por mais tempo; acredite, nunca virá. Restou-lhe um quê de modéstia. Não contendem com o cálamo aqueles que são implacáveis com a língua, seja porque sentem vergonha da própria escrita seja porque isto para eles seria uma confissão de ignorância: não querem mostrar a frivolidade das armas com as quais estão investidos, e por esse motivo, segundo o costume dos Partas, praticam um tipo de combate fugidio e que atira palavras ao vento como se contra os ares arremessasse lanças. [3] Com eles, como disse, é temerário contender à sua maneira, visto que tiram seu máximo prazer da contenda e têm por propósito não encontrar o verdadeiro mas altercar. E, entretanto, é de Varrão o provérbio: "Ao altercar demasiadamente, perde-se a verdade". [4] Mas náo receies, todavia, que desçam ao campo aberto da escritura e da conversaçáo franca; pois decerto é a respeito desse tipo de homens que falava Quintiliano em suas Instituiçôes Oratórias: "Embora possas encontrar alguns homens admiravelmente habilidosos em disputar, quando renunciam à cavilação, não se detém em uma ação de importância mais do que certos pequenos animais, os quais, ágeis em espaço estreito, fazem-se apanhar em campo aberto." ${ }^{" 36} \mathrm{E}$ sendo assim, eles temem com razão o campo aberto. Pois é verdadeira outra passagem deste mesmo autor: "As vias tortuosas e a sinuosidade são a escolha da fraqueza, para que possam se beneficiar com as curvas aqueles que pouco valem na correnteza." ${ }^{37}$

Mas a ti, meu caro amigo, desejaria dizer uma única coisa: se a virtude, se a verdade persegues, evita essa classe de homens. [5] Mas para onde fugiremos das vistas destes insanos, se nem mesmo as ilhas estão a salvo? Se nem mesmo Cila e Caríbdis impediram que esta peste atravessasse a nado para a Sicília? É bem verdade que, se ao exército britânico dos dialéticos agora tiver se juntado a fileira dos novos Ciclopes, isso é já um mal peculiar das ilhas. Afinal, eu não li na cosmografia de Pompônio que a Sicília se assemelha bastante à Inglaterra ${ }^{38}[6] \mathrm{Na}$ verdade, eu acreditava que essa semelhança consistia na posição destas terras, na forma quase triangular de ambas e, talvez ainda na contínua colisão do mar à sua volta; eu não pensava absolutamente nos dialéticos. Ouvira falar que, primeiro, vieram os

\footnotetext{
${ }^{35}$ Tradução de Sergio Xavier G. de Araújo e Edson D. Querubini. Revisão e notas de Sergio Xavier G. de Araújo e Bianca Fanelli Morganti.

${ }^{36}$ Cf. QUINTILIANO, Inst. Orat. 12.2.14

${ }^{37}$ Cf. QUINTILIANO, Inst. Orat. 9.2.78

${ }^{38}$ Cf. POMPÔNIO MELA, De chorogr., 3.6.50
} 
Ciclopes, depois, os tiranos, uns e outros cruéis habitantes; não tinha tido notícia de que uma terceira espécie de monstros havia ali chegado, armada do entimema de dois gumes e mais insolente que a agitação do mar de Taormina: [7] Eu mesmo, de fato, já havia me dado conta de uma coisa, para a qual tu agora me chamas a atenção: eles protegem sua seita sob o esplendor do renome aristotélico, pois dizem que Aristóteles costumava disputar da mesma maneira. Admito, aderir às pegadas de um guia ilustre é uma desculpa de peso, pois até mesmo Cícero diz que, voluntariamente, erraria com Platão se lhe conviesse. ${ }^{39}$ Mas eles estão enganados. [8] Pois Aristóteles, homem de engenho brilhante, tanto disputava quanto escrevia, alternadamente, sobre matérias as mais elevadas; caso contrário, de onde viriam suas tấo numerosas obras, produzidas com supremo esforço e táo longas vigílias, em meio às árduas ocupaçôes com seus muitos discípulos e, em especial, com o mais afortunado deles; e isso tudo ao longo de uma vida não longa? De fato, temos notícias de que ele faleceu por volta daquela idade considerada nefasta pelos escritores, a saber, com cerca de 63 anos. ${ }^{40}$ [9] Mas por que esses homens se afastam tão distoantes do seu guia? Por que, eu pergunto, lhes agrada serem chamados aristotélicos e não antes os envergonha? Nada se assemelha menos a este grande filósofo do que um homem que nada escreve, que compreende pouco, que grita muito e inutilmente.

[10] Quem não zombaria daquelas conclusóezinhas com as quais esses homens letrados fatigam a si mesmos e aos outros, nas quais consomem toda a vida, tornando-se inúteis para as outras coisas e, por isso mesmo, particularmente danosos ? $^{41}$ [11] São essas mesmas coisas que, em muitas passagens, são ridicularizadas por Cícero e Sêneca: ${ }^{42}$ e desse mesmo tipo é aquela resposta de Diógenes, a quem um insolente dialético teria se dirigido com as seguintes palavras: "Tu não és o que eu sou", Diógenes consentiu; aquele então acrescentou "Bem, eu sou um homem"; como também não negara isso, o ardiloso extraiu a sua conclusão: "portanto tu não és homem". Responde Diógenes: "Sem dúvida essa última asserção é falsa, e se quiseres torná-la verdadeira, começa por mim." ${ }^{\text {"ł3 }}$ [12] Há muitas coisas extremamente ridículas como essa, em meio às quais eles buscam algo — ou fama, ou divertimento, ou um modo de viver bem e feliz - eles próprios talvez saibam o que buscam, mas para mim nada é mais obscuro. Pois o lucro deve parecer aos nobres engenhos como uma recompensa indigna aos seus estudos; é próprio dos que se dedicam às artes mecânicas obter lucros, o fim das artes honestas é mais generoso. [13] Cada vez que ouvem estas coisas, ficam irados; assim, o falatório do homem contencioso se aproxima da ira. E dizem eles, "tu então con-

\footnotetext{
${ }^{39}$ Cf. Cícero, Tusc. 1.17.40.

${ }^{40}$ Cf. AULO GELIO, Noct. Att. 5.13.51; 15.7.1-2; CENSORINUS, De die nat., 14.9; FIRMICUS MATERNUS, Math. 4.20. Cf. PÈTRARQUE, Lettres Familières I-III, op. cit., e cf. também PETRARCA, Seniles 8.1 (carta em que Petrarca retoma o tema, pois estaria, em 1366, prestes a completar 63 anos de idade.

${ }^{41}$ Cf. CÍCERO, Tusc. 2. 18. 42

${ }^{42}$ CÍCERO, Academic. 24.75 e SÊNECA, Epist. ad Lucil. 48.4ss.; 49.5ss. e 111. 1.

${ }^{43}$ AULO GÉLIO, Noct. Att. 18.13.7-8.
} 
denas a dialética?" Longe disso; pois eu sei quanta importância atribuíam a ela os estoicos, seita de filósofos forte e valorosa, da qual nosso Cícero lembra no livro De Finibus, ${ }^{44}$ bem como em tantas outras obras suas. Sei que ela é uma das artes liberais, que é um passo para os que almejam coisas elevadas, e para os que passeiam em meio às selvas dos filósofos é uma armadura nada inútil. ${ }^{45}$ Instiga a inteligência, aponta o caminho da verdade, mostra como evitar falácias; por fim, se não tivesse nenhuma outra utilidade, ela nos torna atentos e mais argutos.

Não nego que assim seja. [14] Mas não se segue imediatamente daí que por onde passamos com retidão, nos demoramos com louvor. Ao contrário, é próprio do viajante insano esquecer, por causa da amenidade dos caminhos, a meta que buscava; mas é um mérito do viajante cruzar rapidamente muitas estradas e nunca se deter aquém do seu termo. E quem dentre nós não é um viajante? Todos nós, em breve e adverso tempo, tal como em um dia de chuva invernal, percorremos um itinerário longo e difícil, do qual a dialética pode ser uma parte, de modo algum o término; e pode ser a parte matutina, náo a noturna. [15] De fato, fizemos outrora muitas coisas honestamente que agora faríamos da maneira mais torpe; pois se, quando velhos, ainda desconhecemos como abandonar as escolas de dialética simplesmente porque nelas brincamos quando crianças, por esse mesmo princípio, brincar de par ou ímpar, galopar em cavalinho de pau ou voltar a ser acalentado no berço não deveriam ser motivos de vergonha. ${ }^{46}$ São admiráveis as variedades das coisas e as vicissitudes dos tempos, as quais a natureza, contrapondo-as ao fastio, com vigilantíssimo artifício planejou. Não penses que essas coisas são descobertas num lapso de tempo apenas, mas somente no curso de uma vida muito mais longa.

[16] A primavera é pródiga de flores e folhagens, o verão é rico em colheitas, o outono em frutos, o inverno abunda em neve. Estas coisas, não apenas toleráveis, mas agradáveis, se, contudo, forem alteradas, tornar-se-ão importunas por perturbar as leis da natureza. E assim como não haverá ninguém que suporte, calmamente, seja o gelo de Jano durante o verão, seja o escaldante calor do sol nos outros meses, do mesmo modo não se encontrará quem não odeie ou ridicularize um velho que brinca com crianças, ou quem não se espante com um menino grisalho ou que sofre de gota. [17] Mas o que, eu pergunto, é tâo útil, ou melhor, táo necessário para toda disciplina quanto o conhecimento primeiro das letras, nas quais consistem os fundamentos de todos os estudos? Por outro lado, o que é mais ridículo do que um velho dedicado a essas coisas? [18] Tu, pois, provoca com as minhas palavras os discípulos deste velho; e náo os aterrorize mas os exorte, não por certo para que corram rumo à dialética mas a coisas melhores por meio dela. Ao velho, todavia, dize que não condeno as artes liberais, mas os velhos pueris; pois, conforme diz Sêneca, assim como nada é mais torpe

\footnotetext{
${ }^{44}$ Cf. CÍCERO, De finibus 3.21.72 e 4.4.8-10.

${ }^{45}$ Cf. ISIDORO DE SEVILHA, Etymol. 1.2.1; 2.22.

${ }^{46}$ HORÁCIO, Sat. 2.3.248.
} 
do que um velho aprendiz das primeiras letras, do mesmo modo nada é mais disforme do que um velho dialético. ${ }^{47} \mathrm{E}$, se ele resolver vomitar silogismos, foge, aconselho-te, e manda-o disputar com o Encélado. ${ }^{48}$ Passa bem.

De Avignon, 12 de março.

\section{Referências bibliográficas}

\section{Ediçôes criticas}

PETRARCA. Familiares. Edizione Critica per cura di V. Rossi. (volume 4 a cura di U. Bosco). Florença: Sansoni, 1933-42. 4 volumes.

PÈTRARQUE. Lettres Familières. Paris: Belles Lettres, 2002.

SÊNECA. Ad Lucilium Epistulae Morales. Oxford Classical Texts. Oxford: Clarendon Press, 1965.

\section{Bibliografia secundária}

BAUSI, Francesco. Petarca Antimoderno. Florença: Franco Cesati Editore, 2008.

BERRA, Claudia (Org.). Motivi e Forme Delle Familiari di Francesco Petrarca. Miláo: Monduzzi Editore, 2003.

BIANCHI, Luca. Il vescovo e i filosofi. La condanna parigina del 1277 e l'evoluzione dell'aristotelismo scolastico. Bérgamo: Pierluigi Lubrina Editore, 1990

BIANCHI, Luca; RANDI, Eugenio. Le verità dissonanti - Aristotele alla fine del medioevo. Roma-Bari: Laterza, 1990.

DAMSCHEM, Gregor; HEIL, Andreas (Orgs.). The Brill's Companion to Seneca. Leiden-Boston: Brill Academic Pub., 2014.

DOTTI, Ugo. Vida de Petrarca. Sáo Paulo: Editora da Unicamp, 2006.

GARIN, Eugenio. Idade Média e Renascimento. Lisboa: Estampa,

GILSON, Etienne. A Filosofia na Idade Média. São Paulo: Martins Fontes, 2007.

MORGANTI, Bianca Fanelli. Invective contra Medicum de Francesco Petrarca: tradução, ensaio introdutório e notas. Tese (doutorado em Teoria e História Literária) - Programa de Pós-Graduação em Teoria e História Literária, Universidade Estadual de Campinas. Campinas, 2008.

QUILLEN, Carol. Rereading Renaissance Humanism, Petrarch, Augustine and the language of Humanism. Michigan: University of Michigan Press, 1998.

\footnotetext{
${ }^{47}$ Cf. SÊNECA, Epist. ad Lucil., 36.4.

${ }^{48}$ Cf. VIRGÍlLIO, Eneida, 3.5.78-5.82. 
SETAIOLI, Aldo. Facundus Seneca. Aspetti della lingua e dell'ideologia senecana. Bolonha: Pàtron, 2000.

TIN, Emerson. A Arte de escrever cartas. Sáo Paulo: Editora da Unicamp, 2005. 